\title{
The Design of Media on Two-Lens System Experiment (MTLSE) for Pre-service Physics Teachers
}

\author{
Saprudin $^{1,4, a)}$ Liliasari $^{1, b)}$, Ary Setijadi Prihatmanto ${ }^{2, c)}$, Andhy Setiawan ${ }^{3, d)}$ \\ ${ }^{1}$ Program Studi Pendidikan Ilmu Pengetahuan Alam, Sekolah Pascasarjana, \\ Universitas Pendidikan Indonesia \\ ${ }^{2}$ Sekolah Teknik Elektro dan Informatika, Institut Teknologi Bandung \\ ${ }^{3}$ Program Studi Fisika, Fakultas Pendidikan Matematika dan Ilmu Pengetahuan Alam, \\ Universitas Pendidikan Indonesia \\ ${ }^{4}$ Program Studi Pendidikan Fisika, Fakultas Keguruan dan Ilmu Pendidikan, Universitas Khairun \\ : a) Saprudin@ unkhair.ac.id, ${ }^{\text {b) }}$ liliasari@upi.edu, ${ }^{c}$ arysetijadi@1skk.ee.itb.ac.id, ${ }^{\text {d) }}$ andhys@ @upi.edu
}

\begin{abstract}
This article is a part of the research in designing a model of the geometrical-optics game on optics' courses for pre-service physics teachers (PPTs). This article describes the preliminary form of product, the result of validation, and PPTs' responses to the media on two-lens system experiment (MTLSE). The validation of this media has been done according to physics subject matter, instructional media and pedagogical experts. The implementation of MTLSE using the one-shot case study design involving 25 PPTs at one of the Islamic universities in Bandung. We collected the data of MTLSE validation and PPTs' responses through non-test techniques with questionnaire instruments. The data using quantitative descriptive analysis technique. The results of MTLSE validation can be good categorized. Besides, generally, the PPTs' responses are good categorized toward the implementation of MTLSE on optics' courses.
\end{abstract}

Keywords: design of media, two-lens system experiment, pre-service physics teachers

\section{INTRODUCTION}

Optics is a branch of physics that deals with the behavior and characteristics of light and other electromagnetic waves (Young \& Freedman 2003). Geometrical optics is one branch of optics that discusses light based on the propagating properties of light that traveling in straight lines, explaining the reflection and refraction of light, and being the foundation for making the optical equipment (Saprudin 2018). The term geometrical optics appears as a result of the critical role of geometry in analyzing how the formation of images when the light rays reflected by a mirror and refracted through lenses (Young \& Freedman 2003).

The two-lens system is part of the geometrical optics learning material that is found to still have low competency achievement (Saprudin, Liliasari, \& Prihatmanto 2017). The results of concept analysis show that in general, the concepts in the geometrical optics learning material are dominated by concrete concept labels that are defined from real optical phenomena are easily found in everyday life applications (Saprudin 2018). However, the results of observations at the location of the study showed that the limitations of the physics experiment tools became one of the factors that caused the two-lens system experiment not to be carried out. It creates the pre-service physics teachers (PPTs) at the research location to have difficulty in understanding the concepts in this material. 
The researchers have shown that in its implementation, the teaching and learning process of optics material that has been carried out is dominated by the application of various approaches, models, or methods of learning, and the use of various instructional media ranging from traditional media to the more sophisticated media. This geometrical-optics learning activity is inseparable from hands-on activities that are carried out in real physical activities or through the assistance of virtual media.

The learning approaches, models, or methods that have been applied in optics learning at the level of elementary school, middle school, and higher education includes learning through multiple representation (Hettmannsperger, Mueller, Scheid, \& Schnotz 2016), active learning (Masters \& Grove 2010), experiment-based learning (Even, Balland, \& Guillet 2016; Grusche 2017), inquiry based learning (Kotsari \& Smyrnaiou 2017; Srisawasdi \& Kroothkeaw 2014), constructivism approach (Taşlidere 2013), STEM (King \& English 2016), interactive engagement pedagogy (Sorensen, McBride, \& Rebello 2011), problem solving (Warimun 2012), project based learning model (Oktarinah, Wiyono, \& Zulherman 2016; Suranti, Gunawan, \& Sahidu 2016), lesson study (Manrulu \& Sari 2015), cooperative learning (Sutarno \& Putri 2012), contextual learning (Suniati, Sadia, \& Suhandana 2013), problem based learning (Hidayat, Danawan, \& Hidayat 2013), science techology society (Gunarto \& Hidayah 2014), Kolb's experiential learning model (Jannati 2016) and integrated science learning (Madesa \& Permanasari 2015; Oktamagia, Fauzi, \& Hidayati 2013).

As the development of science and technology is getting faster, the use of instructional media is one alternative that can be done to improve the effectiveness of physics learning. Therefore, the use of diverse instructional media is one of the aspects of assessment in school accreditation, especially in the standard process (Rahman, Saprudin, Mubarak, \& Hamid 2017; Saprudin \& Hamid 2018). Various media used in optical learning include; the media of optical objects in the surrounding environment (Hasanah 2012), optics kit (Pratiwi, Murniati, \& Fathurohman 2013; Prihatiningtyas, Prastowo, \& Jatmiko 2013), studio optics (Sorensen et al. 2011), concept cartoon work sheets (Taşlidere 2013), pocket book (Laksita, Supurwoko, \& Budiawanti 2013), physics flipbook (Hayati, Budi, \& Handoko 2015), pop-up book (Ukhtinasari, Mosik, \& Sugiyanto 2017), virtual simulation (Martínez, Naranjo, Pérez, Suero, \& Pardo 2011; Permana, Widiyatmoko, \& Taufiq 2016; Prihatiningtyas et al. 2013; Prihatiningtyas, Prastowo, \& Jatmiko 2012; Srisawasdi \& Kroothkeaw 2014), virtual laboratory (Collier, Dunham, Braun, \& O’Loughlin 2012; Escobar, Sánchez, Beltrán Hoz, \& González 2016), tracker (Rodrigues \& Simeão Carvalho 2014), multimedia (García-Martínez et al. 2015; Gunawan, Harjono, Sutrio, \& Sahidu 2013; Putri \& Supardi 2015; Suniati et al. 2013; Sutarno \& Putri 2012), prezi online (Utari, Kurniawan, \& Fatmaryanti 2014), MOODLE or Modular Object-Oriented Dynamic Learning Environment (Sampurno, Maulidiyah, \& Puspitaningrum 2015), games (Estiani, Widiyatmoko, \& Sarwi 2015; Fitria \& Widiyatmoko 2015; Novitasari, Supurwoko, \& Surantoro 2013), augmented reality (Putri, Bakri, \& Permana 2016), mobile network (Zhou, Zhao, $\&$ Chen 2017). The forms of games used in optics learning include edutainment-based science circuit adopted from monopoly games, games with UNO cards, and also information technology-based instructional media in the way of snakes and ladders.

As a first step in designing geometrical-optics games aimed for PPTs, researchers consider it necessary to create a media and experimental procedures that can provide learning experiences related to the concept of the two-lens system. Besides, this study describes the results of validation and PPTs' responses to the implementation of media on two-lens system experiment (MTLSE) in the optics course.

\section{RESEARCH METHODOLOGY}

This research conduct in a pre-experimental design with a one-shot case study design. In this research, one subject group namely 25 PPTs in one of the Islamic Universities in Bandung was subject to treatment in the form of lectures using the MTLSE, then after that, measurements were done regarding the PPTs' responses to the implementation of MTLSE in the courses. Before being used, MTLSE is validated in advance both from the material aspects of physics, instructional media, and pedagogics.

The subject of validation involved two physics material experts, two instructional media experts, and two pedagogical experts. The data related to MTLSE validation collected through non-test 
techniques with validation sheet instruments which packaged in the form of a questionnaire with closed-ended questions. The data associated with PPTs' responses to the implementation of MTLSE in lectures collected through the questionnaires. The data analysis techniques were carried out using quantitative descriptive analysis techniques.

\section{RESULTS AND DISCUSSION}

\section{The Design of Media on Two-Lens System Experiment (MTLSE)}

The central principle of MTLSE is to find various combinations of lenses at a certain distance that can produce the sharpest image under certain conditions. Multiple combinations of lenses with a certain distance between lenses found through experiments will be analyzed and compared with the results of mathematical calculations. The PPTs will also be required to think creatively in finding possible lens combinations, and also required to think critically in analyzing and comparing the data from experiments with mathematical calculation results.

The apparatus used in designing this MTLSE include; Econo curtain rails, $12 \mathrm{~mm}$ plywood, $3 \mathrm{~mm}$ thin plywood, $12 \mathrm{~mm}$ aluminum clips, $12 \mathrm{~mm}$ bolts, biconvex lenses $(\mathrm{f}=+50 \mathrm{~mm},+100 \mathrm{~mm},+150$ $\mathrm{mm},+200 \mathrm{~mm}$ and $+250 \mathrm{~mm}$ ), biconcave lens ( $\mathrm{f}=-50 \mathrm{~mm},-100 \mathrm{~mm},-150 \mathrm{~mm},-200 \mathrm{~mm}$ and -250 $\mathrm{mm}$ ), arrow diaphragm, white screen, lens holder, screen holder, arrow diaphragm holder, measuring tape, LED lights source (MR16, 4.5W) and LED spotlight. The MTLSE design shown in FIGURE 1.

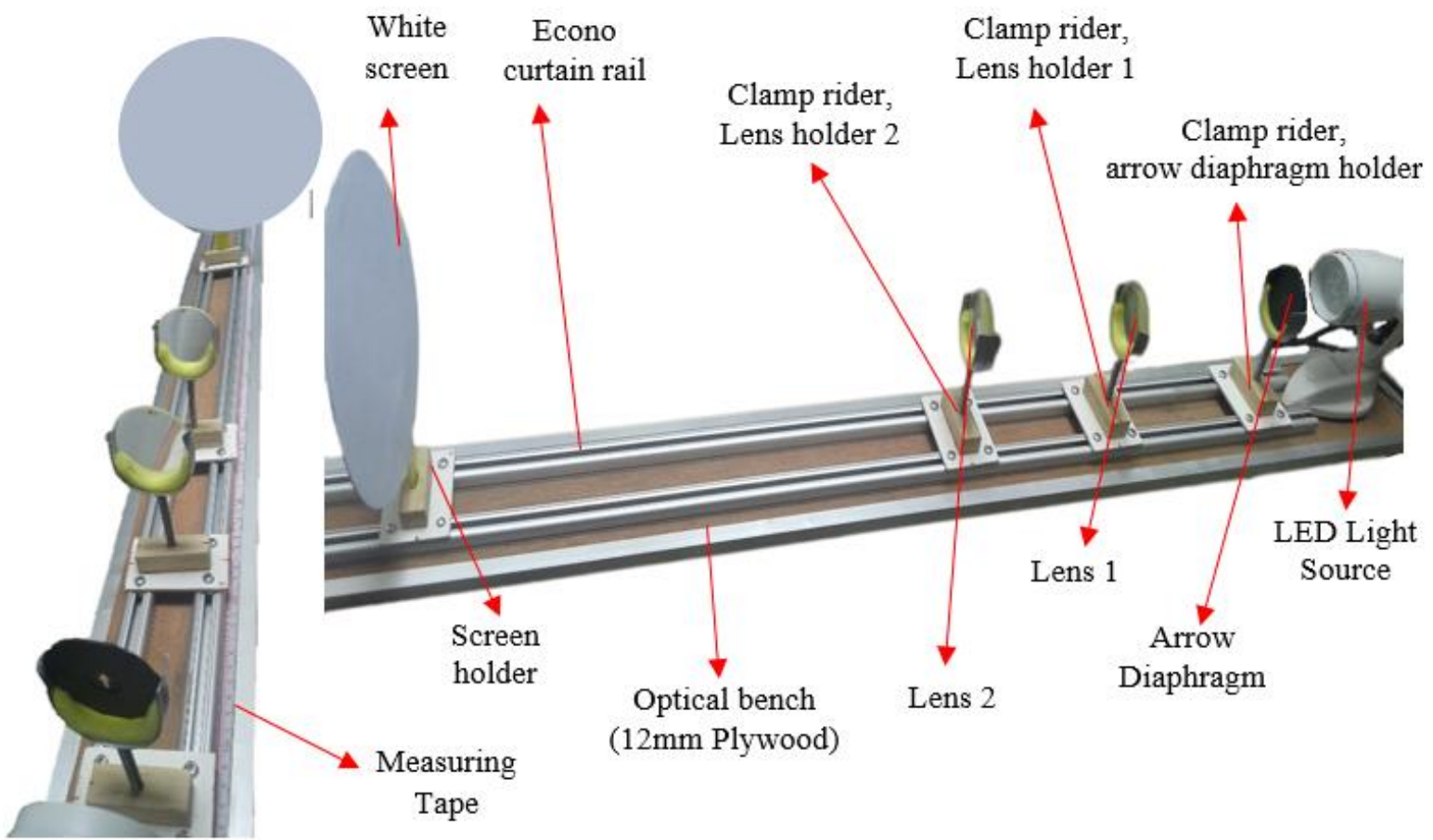

(a)

(b)

FIGURE 1. The Display of Media on Two-Lens System Experiment (MTLSE); (a) front view, (b) side view 
FIGURES 2, 3a and 3b show the sample result of PPTs' experimental data and mathematically analysis.

\begin{tabular}{|c|c|c|c|c|c|c|c|}
\hline $\begin{array}{c}\text { Types of } \\
\text { lens 1 }\end{array}$ & $\begin{array}{c}\text { Types of } \\
\text { lens 2 }\end{array}$ & $\begin{array}{c}\text { Focal } \\
\text { length of } \\
\text { lens 1 } \\
(\mathrm{mm})\end{array}$ & $\begin{array}{c}\text { Focal } \\
\text { length of } \\
\text { lens 2 } \\
(\mathrm{mm})\end{array}$ & $\begin{array}{c}\text { Distance of } \\
\text { the object } \\
\text { from the lens } \\
1(\mathrm{~cm})\end{array}$ & $\begin{array}{c}\text { Distance of } \\
\text { the image } \\
\text { from the lens } \\
2(\mathrm{~cm})\end{array}$ & $\begin{array}{c}\text { Distance } \\
\text { between } \\
\text { two lens } \\
(\mathrm{cm})\end{array}$ & $\begin{array}{c}\text { Image } \\
\text { form }\end{array}$ \\
\hline $\begin{array}{c}\text { bikonveks } \\
(+)\end{array}$ & $\begin{array}{c}\text { bikonveks } \\
(+)\end{array}$ & 250 & 200 & 10,6 & 50 & 14,4 & $\begin{array}{c}\text { Inverted, } \\
\text { Enlarged }\end{array}$ \\
\hline
\end{tabular}

FIGURE 2. Photo Sample of PPTs' Experimental Data

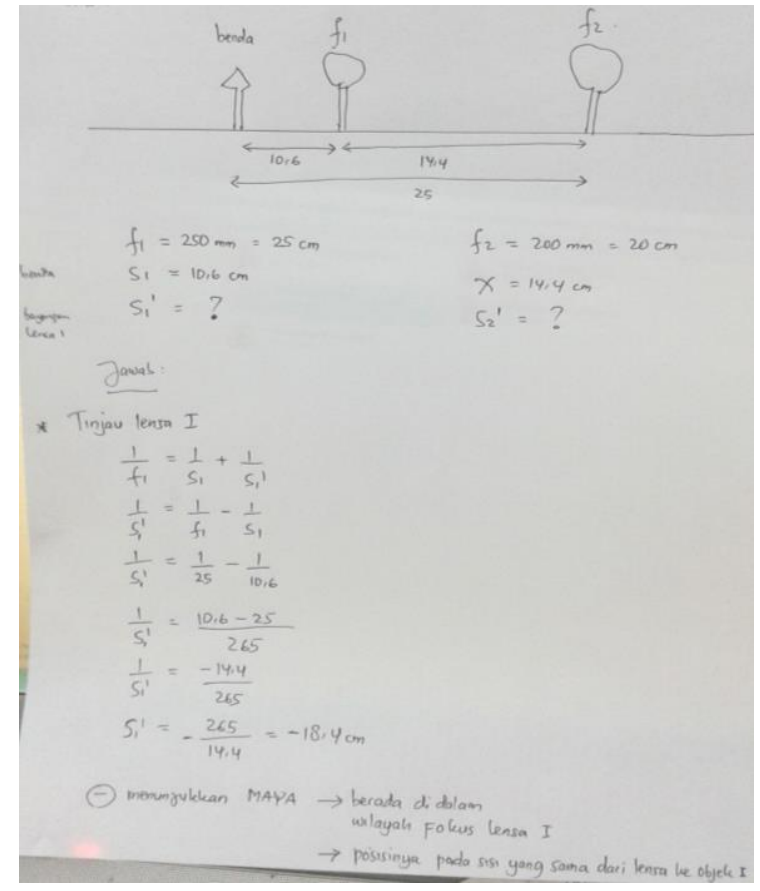

(a)

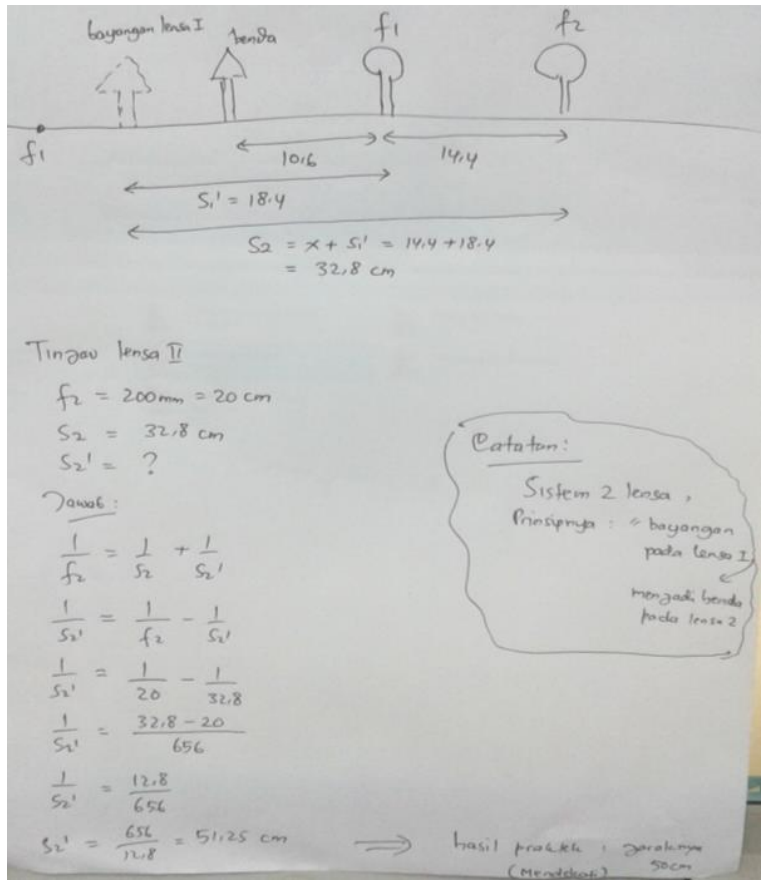

(b)

FIGURE 3. Photo Sample of Mathematical Analysis

\section{Validation Result of Media on Two-Lens System Experiment (MTLSE)}

TABLE 1, TABLE 2, and TABLE 3 show the results of validation by physics matter, instructional media, and pedagogical experts.

TABEL 1. Results of MTLSE Validation by Physics Material Experts

\begin{tabular}{|c|c|c|}
\hline Aspects & Indicators & Percentage $(\%)$ \\
\hline Describing physics phenomena & MTLSE has clarity of objects and physics phenomena & 80 \\
\hline $\begin{array}{l}\text { Possible lens combination } \\
\text { variation }\end{array}$ & $\begin{array}{l}\text { MTLSE produces a variety of lens combinations that can } \\
\text { be found by PPTs }\end{array}$ & 70 \\
\hline $\begin{array}{l}\text { Suitability of experimental } \\
\text { results with mathematical } \\
\text { calculation results }\end{array}$ & $\begin{array}{l}\text { The results of the two-lens system experiment with } \\
\text { MTLSE can be mathematically proven }\end{array}$ & 80 \\
\hline $\begin{array}{l}\text { Provides clarity on the concept } \\
\text { of a two-lens system }\end{array}$ & $\begin{array}{l}\text { MTLSE can increase transparency to the concept of image } \\
\text { formation by the lens } \\
\quad \text { Average }\end{array}$ & 70 \\
\hline
\end{tabular}


TABEL 2. Results of MTLSE Validation by Instructional Media Experts

\begin{tabular}{llc}
\hline \multicolumn{1}{c}{ Aspects } & \multicolumn{1}{c}{ Indicators } & Percentage (\%) \\
\hline Efficiency & Ease of assembling MTLSE & 80 \\
& Ease of operating the MTLSE & 70 \\
& MTLSE can be used in groups & 80 \\
& MTLSE does not take long to use & 60 \\
& MTLSE is easy to carry and store back in its place & 80 \\
Accuracy and Precision & Accuracy of measurement & 70 \\
& The consistency of experimental results & 80 \\
Clarity of the images formed & 80 \\
& The MTLSE is resistant to environmental vibrations that can change & 80 \\
& measurement results & 60 \\
& The resilience of the components in each stand or each clamp rider & 70 \\
The lens used is resistant to scratches & 60 \\
& The lens used is not easily broken if it falls & 80 \\
The light source used is safe for the eyes & 80 \\
Testhetics & The power source used is safe for the user & 80 \\
& Construction tools are safe for users & 70 \\
& MTLSE has an interesting shape & $\mathbf{7 4}$ \\
\hline
\end{tabular}

TABEL 3. Results of MTLSE Validation by Pedagogical Expert

\begin{tabular}{llc}
\hline \multicolumn{1}{c}{ Aspects } & \multicolumn{1}{c}{ Indicators } & Percentage (\%) \\
\hline Linkages with the curriculum & MTLSE provides learning experiences by the demands of the & 80 \\
(Syllabus/ GBRP/ RPS/ SAP) & KKNI (IQF) & 80 \\
& MTLSE has clarity of objects and physical phenomena & 80 \\
Suitability with the level of & Suitability of the MTLSE with the level of the intellectual & 90 \\
intellectual development & development of PPTs & 60 \\
Practicing science process skills & MTLSE provides a learning experience especially on observing & 60 \\
& Making observations) & 70 \\
& MTLSE provides a learning experience on classifying & 60 \\
& MTLSE provides a learning experience on interpreting & 60 \\
& MTLSE provides a learning experience on predicting & 60 \\
& MTLSE provides a learning experience on communicating & 70 \\
& MTLSE provides a learning experience on questioning & 80 \\
& MTLSE provides a learning experience on designing an & 80 \\
& experiment & 80 \\
& MTLSE provides a learning experience using tools/ apparatus/ & 80 \\
& materials/ sources & 80 \\
MTLSE provides a learning experience on applying concepts & $\mathbf{7 3}$ \\
\hline
\end{tabular}

Overall, the results of MTLSE validation according to the physics matter experts are categorized as good (75\%), according to the instructional media experts are classified as good (74\%), and according to the pedagogical experts are classified as good (73\%). Based on that, MTLSE can be declared as feasible for use in the optical course.

\section{PPTs' Responses toward The Implementation of MTLSE}

PPTs' responses are focused on two target focuses namely; 1) PPTs' responses toward MTLSE and 2) PPTs' responses toward two-lens system experiment design. TABLE 4 and TABLE 5 show the PPTs' responses.

TABLE 4. PPTs' Response to MTLSE and Experimental Design of Two-Lens Systems

\begin{tabular}{|c|c|c|}
\hline No & Indicators & Percentage (\%) \\
\hline 1 & PPTs' responses to MTLSE & 77 \\
\hline 2 & PPTs' responses to the two-lens system experiment design & 79 \\
\hline
\end{tabular}


TABLE 5. PPTs' Responses Toward MTLSE

\begin{tabular}{clc}
\hline No & \multicolumn{1}{c}{ Statements } & Percentage (\%) \\
\hline 1 & This MTLSE display is impressive to use & 84 \\
2 & MTLSE is easy to operate & 88 \\
3 & The final image produced by MTLSE can be observed on the screen & 85 \\
4 & Shifting tool components of MTLSE are easy to do & 83 \\
5 & The light source at the MTLSE does not interfere during the observation & 46 \\
6 & I have experimented with two lens systems & 78 \\
7 & This two-lens system experiment is a new thing for me & 75 \\
8 & The use of MTLSE can increase my motivation to study physics more deeply & 78 \\
9 & MTLSE can make it easier to understand the material related to the image & 80 \\
& formation on the two-lens system & 83 \\
10 & With MTLSE, the two-lens lab experiment becomes more interesting & 80 \\
11 & I feel the subject matter lasts longer in memory if explained using MTLSE \\
12 & The challenge of determining the lens combination that produces the sharpest & 77 \\
& $\begin{array}{l}\text { image/ shadow is an interesting thing to solve } \\
13\end{array}$ & $\begin{array}{l}\text { I was demanded to think creatively to find a lens combination that produced the } \\
\text { sharpest image/ shadow }\end{array}$ \\
14 & $\begin{array}{l}\text { From the various lens combinations found, I am required to think critically in } \\
\text { producing the best lens combination }\end{array}$ & 78 \\
15 & $\begin{array}{l}\text { Through this MTLSE, I was motivated to find as many lens combinations as } \\
\text { possible }\end{array}$ & 78 \\
& & 78
\end{tabular}

Overall, PPTs gave good responses to the MTLSE and also to the two-lens system experiment design. It is indicated by the total score of 1415 from a maximum score of 1800 . The results of the questionnaire suggest that this experimental design is considered as something new for PPTs at the research location.

\section{CONCLUSION}

The main principle of MTLSE is finding various combinations of lenses at a certain distance that can produce the sharpest image under certain conditions. Different lens combinations that found through experiment will be analyzed and compared with the results of mathematical calculations. Some of the advantages of MTLSE that have been designed include; a) easy to operate, b) the image that formed by two-lens system can be clearly observed on the screen, c) shifting the components of MTLSE (the object distance, image distance, and the distance between two lenses) are easy to do, and d) using LED light source so do not disturb the eyes during observation.

The results of MTLSE validation according to physics material, instructional media and pedagogical experts can be categorized as good. Besides, PPTs' responses to the implementation of MTLSE are categorized as good. The products and experiment designs produced will be used to design a geometrical-optics game model that can be used in optics course for PPTs.

\section{REFERENCES}

Collier, L, Dunham, S, Braun, MW, \& O'Loughlin, VD 2012, 'Optical versus virtual: Teaching assistant perceptions of the use of virtual microscopy in an undergraduate human anatomy course,' Anatomical Sciences Education, vol. 5, no. 1, pp. 10-19, https://doi.org/10.1002/ase.262.

Escobar, JH, Sánchez, H, Beltrán, JR, Hoz, JDL, \& González, JD 2016, 'Virtual experimentation in electromagnetism, mechanics and optics: Web-based learning,' Journal of Physics: Conference Series, vol. 687, no. 1, https://doi.org/10.1088/1742-6596/687/1/012078.

Estiani, W, Widiyatmoko, A, \& Sarwi 2015, 'Pengembangan Media Permainan Kartu UNO untuk Meningkatkan Pemahaman Konsep dan Karakter Siswa Kelas VIII Tema Optik', Unnes Science Education Journal, vol. 4, no. 1, pp. 711-719. 
Even, C, Balland, C, \& Guillet, V 2016, 'Learning through experimenting: An original way of teaching geometrical optics,' European Journal of Physics, vol. 37, no. 6, https://doi.org/10.1088/0143-0807/37/6/065707.

Fitria, R, \& Widiyatmoko, A 2015, 'Pengembangan Media Science Circuit Berbasis Edutainment pada Pembelajaran IPA Tema Optik untuk Meningkatkan Minat dan Hasil Belajar Siswa', Unnes Science Education, vol. 4, no. 1, pp. 763-771.

García-Martínez, P, Zapata-Rodríguez, CJ, Ferreira, C, Fernández, I, Pastor, D, Nasenpour, M, ... Miret, JJ 2015, 'Innovative education networking aimed at multimedia tools for geometrical optics learning,' In Proceedings of SPIE, vol. 9793, p. 97930L-1, https://doi.org/10.1117/12.2223077.

Grusche, S 2017, 'Developing students' ideas about lens imaging: Teaching experiments with an image-based approach,' Physics Education, vol. 52, no. 4, https://doi.org/10.1088/13616552/aa6d27.

Gunarto, W, \& Hidayah, N 2014, 'Upaya Meningkatkan Minat Belajar dan Prestasi Belajar Siswa Pada Materi Pembelajaran Alat-Alat Optik Melalui Pendekatan Sains Teknologi Masyarakat di Kelas VIII SMPN 3 Belitang Madang Raya', Jurnal Inovasi dan Pembelajaran Fisika, vol. 1, no. 1, pp. $28-32$.

Gunawan, Harjono, A, Sutrio, \& Sahidu, H 2013, 'Multimedia Interaktif pada Materi Optik: Karakteristik dan Keunggulannya', Jurnal Kependidikan, vol. 12, no. 2, pp. 133-140.

Hasanah, U 2012, 'Upaya Meningkatkan Pemahaman Konsep Cahaya Melalui Pemanfaatan Media Pembelajaran Benda Optik di Lingkungan Sekitar pada Siswa Kelas VIII D SMP Negeri 2 Temon Tahun Pelajaran 2010/2011', Jurnal Ilmiah Guru Caraka Olah Pikir Edukatif, vol. 16, no. 1, pp. $7-18$.

Hayati, S, Budi, AS, \& Handoko, E 2015, 'Pengembangan Media Pembelajaran Flipbook Fisika untuk Meningkatkan Hasil Belajar Peserta Didik', In Prosiding Seminar Nasional Fisika (ejurnal) SNF2015, vol. IV, pp. 49-54.

Hettmannsperger, R, Mueller, A, Scheid, J, \& Schnotz, W 2016, 'Developing conceptual understanding in ray optics via learning with multiple representations', Zeitschrift Für Erziehungswissenschaft, vol. 19, no 1, pp. 235-255. https://doi.org/10.1007/s11618-015-0655-1.

Hidayat, AL, Danawan, A, \& Hidayat, A 2013, 'Penerapan Model Problem Based Learning Pada Pembelajaran Optik untuk Meningkatkan Kemampuan Berpikir Kreatif dan Prestasi Belajar Siswa SMP', Jurnal Wahana Pendidikan Fisika, vol. 1, no. 1, pp. 55-65.

Jannati, ED 2016, 'Model Pembelajaran Experiential Kolb untuk Meningkatkan Kemampuan Menjelaskan Fenomena Fisis Pada Konsep Optik', Gravity: Jurnal Ilmiah Penelitian dan Pembelajaran Fisika, vol. 2, no. 2, pp. 143-155.

King, D, \& English, LD 2016, 'Engineering design in the primary school: applying STEM concepts to build an optical instrument,' International Journal of Science Education, vol. 38, no. 18, pp. 2762-2794.

Kotsari, C, \& Smyrnaiou, Z 2017, 'Inquiry-based learning and meaning generation through modeling on geometrical optics in a constructionist environment,' European Journal of Science and Mathematics Education, vol. 5, no. 1, pp. 14-27.

Laksita, SV, Supurwoko, S, \& Budiawanti, S 2013, 'Pengembangan Media Pembelajaran Fisika dalam Bentuk Pocket Book pada Materi Alat Optik Serta Suhu dan Kalor Untuk Kelas X SMA', Jurnal Materi dan Pembelajaran Fisika, vol. 3, no. 1, pp. 14-17.

Madesa, E, \& Permanasari, A 2015, 'Penerapan Pembelajaran IPA Terpadu Tipe Threaded dengan Level of Inquiry untuk Meningkatkan Keterampilan Berpikir Kritis dan Penguasaan Konsep Siswa Kelas VIII pada Tema Indera Penglihatan dan Alat Optik', Edusains, vol 7, no. 2, pp. $143-$ 150. 
Manrulu, RH, \& Sari, DN 2015, 'Efektivis Kegiatan Lesson Study dalam Merancang Pembelajaran pada Mata Kuliah Gelombang dan Optik', Jurnal Ilmiah Pendidikan Fisika Al-Biruni, vol. 4, no. 2, pp. 229-239. https://doi.org/10.24042/jpifalbiruni.v4i2.95.

Martínez, G, Naranjo, FL, Pérez, AL, Suero, MI, \& Pardo, PJ 2011, 'Comparative study of the effectiveness of three learning environments: Hyper-realistic virtual simulations, traditional schematic simulations and traditional laboratory,' Physical Review Special Topics-Physics Education Research, vol. 7, no. 2, 20111. https://doi.org/10.1103/PhysRevSTPER.7.020111.

Masters, MF, \& Grove, TT 2010, 'Active learning in intermediate optics through concept building laboratories,' American Journal of Physics, vol. 78, no. 5, pp. 485-491 https://doi.org/10.1119/1.3381077.

Novitasari, E, Supurwoko, \& Surantoro 2013, 'Pengembangan media pembelajaran berbasis IT berbentuk permainan ular tangga materi alat optik untuk kelas VIII SMP', Jurnal Pendidikan Fisika, vol. 1, no. 1, pp. 37-45.

Oktamagia, DW, Fauzi, A, \& Hidayati 2013, 'Pengaruh Pembelajaran Terpadu Tipe Connected Terhadap Hasil Belajar IPA Fisika pada Materi Cahaya dan Alat Optik di Kelas VIII SMP N 1 Sungai Tarab', Pillar of Physics Education, vol. 2, no. 1, pp. 25-32.

Oktarinah, Wiyono, K, \& Zulherman 2016, 'Pengembangan Bahan Ajar Berbasis Model Pembelajaran Proyek Materi Alat-alat Optik untuk Kelas X SMA', Jurnal Inovasi dan Pembelajaran Fisika, vol. 3, no. 1, pp. 80-85.

Permana, NA, Widiyatmoko, A, \& Taufiq, M 2016, 'Pengaruh Virtual Laboratory Berbasis Flash Animation Terhadap Pemahaman Konsep dan Keterampilan Berpikir Kritis Peserta Didik Tema Optik Kelas VIII SMP', Unnes Science Education Journal, vol. 5, no. 3, pp. 1346-1358.

Pratiwi, I, Murniati, \& Fathurohman, A 2013, 'Pengaruh Metode Praktikum Menggunakan Kit Optik Terhadap Hasil Belajar Siswa pada Pokok Bahasan Cahaya di Kelas VIII SMP Negeri 1 Prabumulih', Jurnal Inovasi dan Pembelajaran Fisika, vol. 1, no. 2, pp. 90-95.

Prihatiningtyas, S, Prastowo, T, \& Jatmiko, B 2012, 'Pengembangan Perangkat Pembelajaran Fisika SMP Berbasis Simulasi Virtual dan Kit Sederhana dengan Model Pembelajaran Langsung dan Kooperatif untuk Mengajarkan Keterampilan Psikomotor dan Afektif pada Pokok Bahasan Alat Optik', JPPS: Jurnal Peneilitian Pendidikan Sains, vol. 2, no. 1, pp. 135-141.

Prihatiningtyas, S, Prastowo, T, \& Jatmiko, B 2013 Implementasi Simulasi PhET dan Kit Sederhana untuk Mengajarkan Keterampilan Psikomotor Siswa pada Pokok Bahasan Alat Optik', Jurnal Pendidikan IPA Indonesia, vol. 2, no. 1, pp. 18-22.

Putri, MP, \& Supardi, ZAI 2015, 'Penggunaan Multimedia Presentasi Teroptimasi pada Materi Alat Optik untuk Meningkatkan Kemampuan Berpikir Kritis', Jurnal Inovasi Pendidikan Fisika (JIPF), vol. 4, no. 2, pp. 116-120.

Putri, WM, Bakri, F, \& Permana, AH 2016, 'Pengembangan Media Pembelajaran Berbasis Multimedia Augmented Reality pada Pokok Bahasan Alat Optik', In Prosiding Seminar Nasional Fisika (E-Journal) SNF2016, vol. V, p. SNF2016-RND-83 - SNF2016-RND-88, https://doi.org/10.21009/0305010218.

Rahman, MH, Saprudin, S, Mubarak, H, \& Hamid, F 2017, 'Evaluasi Program IbM Pendampingan Penyusunan Borang Akreditasi Bagi Sekolah Dasar di Kota Ternate', Titian Ilmu: Jurnal Ilmiah Multi Sciences, vol. IX, no. 2, pp. 59-65.

Rodrigues, M, \& Simeão Carvalho, P 2014, 'Teaching optical phenomena with Tracker', Physics Education, vol. 49, no. 6, pp. 671-677, https://doi.org/10.1088/0031-9120/49/6/671.

Sampurno, PJ, Maulidiyah, R, \& Puspitaningrum, HZ 2015, 'Implementasi Kurikulum 2013 : MOODLE (Modular Object Oriented Dynamic Learning Environment) dalam Pembelajaran Fisika melalui Lembar Kerja Siswa pada Materi Optik di SMA', Jurnal Fisika Indonesia, vol. 19, no. 56 , pp. $54-58$. 
Saprudin, S 2018, 'Analisis Kesiapan dan Strategi Monitoring Evaluasi Program Pengembangan Perkuliahan Gelombang dan Optik Berbasis Game', JIPFRI (Jurnal Inovasi Pendidikan Fisika dan Riset Ilmiah), vol. 2, no. 1, pp. 28-37, https://doi.org/10.30599/jipfri.v2i1.207.

Saprudin, S, \& Hamid, F 2018, 'Efektivitas Penggunaan Multimedia Interaktif Materi Kalor Berorientasi Peta Kompetensi Siswa Sekolah Menengah Atas', Titian Ilmu: Jurnal Ilmiah Multi Sciences, vol. 10, no. 1, pp. 29-38.

Saprudin, S, Liliasari, L, \& Prihatmanto, AS 2017, 'Pre-Service Physics Teachers' Concept Mastery and the Challenges of Game Development on Physics Learning,' In Journal of Physics: Conference Series, vol. 895, https://doi.org/10.1088/1742-6596/895/1/012109.

Sorensen, CM, McBride, DL, \& Rebello, NS 2011, 'Studio optics : Adapting interactive engagement pedagogy to upper-division physics,' American Journal of Physics, vol. 79, no. 3, pp. 320-325, https://doi.org/10.1119/1.3535580.

Srisawasdi, N, \& Kroothkeaw, S 2014, 'Supporting students' conceptual development of light refraction by simulation-based open inquiry with dual-situated learning model,' Journal of Computers in Education, vol. 1, no. 1, pp. 49-79, https://doi.org/10.1007/s40692-014-0005-y.

Suniati, NMS, Sadia, W, \& Suhandana, A 2013, 'Pengaruh Implementasi Pembelajaran Kontekstual Berbantuan Multimedia Interaktif Tehadap Penurunan Miskonsepsi (Studi Kuasi Eksperimen dalam Pembelajaran Cahaya dan Alat Optik di SMP Negeri 2 Amlapura', Jurnal Administrasi Pendidikan, vol. 4, no. 1 .

Suranti, NMY, Gunawan, \& Sahidu, H 2016, 'Pengaruh Model Project Based Learning Berbantuan Media Virtual Terhadap Penguasaan Konsep Peserta Didik pada Materi Alat-alat Optik', Jurnal Pendidikan Fisika dan Teknologi, vol. II, no. 2, pp. 73-79.

Sutarno, M, \& Putri, DH 2012, 'Penerapan Kelompok Kooperatif Berbantuan Multimedia Interaktif untuk Meningkatkan Penalaran Sains dan Penguasaan Konsep Mahasiswa', In Prosiding Seminar Nasional Fisika 2012, pp. 147-152.

Taşlidere, E 2013, 'The Effect of Concept Cartoon Worksheets on Students' Conceptual Understandings of Geometrical Optics,' Education \& Science/Egitim ve Bilim, vol. 38, no. 167.

Ukhtinasari, F, Mosik, M, \& Sugiyanto, S 2017, 'Pop-Up Sebagai Media Pembelajaran Fisika Materi Alat-Alat Optik untuk Siswa Sekolah Menengah Atas', Unnes Physics Education Journal, vol. 6, no. 2, pp. 1-6.

Utari, YP, Kurniawan, ES, \& Fatmaryanti, SD 2014, 'Pengembangan Media Pembelajaran Fisika Online Prezi dalam Pokok Bahasan Alat Optik pada Siswa Kelas X IPA SMA Negeri 3 Purworejo Tahun Pelajaran 2013/2014', Radiasi: Jurnal Berkala Pendidikan Fisika, vol. 5, no. 2, pp. 45-49.

Warimun, ES 2012, 'Penerapan Model Pembelajaran Problem Solving Fisika Pada Pembelajaran Topik Optika Pada Mahasiswa Pendidikan Fisika', Exacta, vol. X, no. 2, pp. 111-114.

Young, HD, \& Freedman, RA 2003, Fisika universitas jilid 2 edisi kesepuluh (diterjemahkan Pantur Silaban), Erlangga, Jakarta.

Zhou, M, Zhao, Q, \& Chen, Y 2017, 'Mobile internet and technology for optical teaching reform in higher education,' In 14th Conference on Education and Training in Optics and Photonics: ETOP 2017, https://doi.org/10.1117/12.2269762. 
